\title{
Influence of the drying step in the steam-jet granulation process of dairy powders
}

\author{
Mathieu Person ${ }^{\mathrm{a}, \mathrm{b}}$, Bernard Cuq ${ }^{\mathrm{b}, *}$, Agnès Duri ${ }^{\mathrm{b}}$, Cécile Le Floch-Fouéréa ${ }^{\text {, Pierre Schuck }}{ }^{\mathrm{a}}$, \\ Romain Jeantet ${ }^{\mathrm{a}}$ \\ a STLO, UMR1253, INRA, Agrocampus Ouest, 35042, Rennes, France \\ ${ }^{\mathrm{b}}$ IATE, UMR1208, INRA, Montpellier SupAgro, Université Montpellier 2, CIRAD, 34060, Montpellier, France
}

\section{A R T I C L E I N F O}

\section{Keywords:}

Steam-jet

Agglomeration

Skim milk powder

Drying

Rehydration

\begin{abstract}
A B S T R A C T
Steam-jet granulation process consists in agglomeration mechanisms promoted by the wetting of fine particles and colliding them to generates the agglomerates, and in consolidation mechanisms of the agglomerates by drying stage. The aim of the present study was to evaluate the influence of the drying step on the properties of the agglomerates. Experiments were conducted using an original pilot system with different drying conditions (time and temperature). We demonstrated that the mechanisms induced by drying stage contribute to the final structure and characteristics of the agglomerates. On the other hand, the changes in drying temperature (70, 90 , or $110^{\circ} \mathrm{C}$ ) did not significantly impact the structural properties. The rehydration properties of the agglomerates were found to depend on the changes in water content. During the first minutes of drying, a rapid decrease of the wetting time of the agglomerates was observed and associated with rapid lactose crystallization. For long drying times, the large decrease in water content induced a considerable increase in the glass transition temperature, leading to a delay in the plasticization effect of the water during rehydration. The drying stage is a key factor to control the stability and functional properties of agglomerates.
\end{abstract}

\section{Introduction}

In the food industry, solubility in water is a critical attribute of most of the powdered products. For example, fast dispersion of powders in water is required for applications such as cocoa and milk powders (Vissotto et al., 2010; Palzer, 2011; Barkouti et al., 2013; Turchiuli et al., 2013). Improving the properties of solubility in water can be obtained by using agglomeration processes, which consist in combining fine native particles to form larger agglomerated porous structures (Jinapong et al., 2008; Ji et al., 2015). The open structures of the agglomerates allow the capillary rise of the dissolving water into the pores, and promote the wetting and sinking steps during the rehydration of the powder (Forny et al., 2011).

Different agglomeration processes, such as agglomeration during drying, fluid-bed agglomeration, steam-jet agglomeration, high shear agglomeration, and pressure agglomeration, are used in the food industry depending on the initial properties of the native particles and the expected functional properties of the agglomerated powders. The steam-jet agglomeration process is classically used in the dairy industry for obtaining instant dairy powders. The high solubility in water of the native dairy components is well adapted to the agglomeration mechanisms involved in steam-jet processing. Furthermore, this process allows native dairy powders to form agglomerates with high porosity and a high dissolution rate, which is a critical attribute of dairy powders (Schuchmann, 1995; Shanmugam, 2015).

During steam-jet agglomeration of dairy powders, steam condensation on the surface of native particles promotes superficial heating and hydration of the particles and plasticization of their hydrophilic components (Hogekamp, 1999). The amorphous lactose contained in the dairy powder can thus undergo glass transition, leading to a decrease in the particle surface viscosity to below $10^{8}$ Pa s (Palzer, 2011). Random collisions between sticky particles then lead to adhesion through the formation of liquid and viscous bridges, which are further solidified during a subsequent drying step by water evaporation (Malafronte et al., 2016). The drying step of the process is mandatory in order to increase the strength of the agglomerates, which have to be enough resistant to prevent erosion, attrition and breakage during transportation or dispensing of the products. The drying step also controls the final water content and water activity of the agglomerates, which must be low enough to prevent any bacterial growth and caking occurrence in the powder during storage.

Despite the industrial relevance of the steam-jet agglomeration

\footnotetext{
* Corresponding author. UMR 1208 INRA IATE, Montpellier SupAgro, 2 place Viala, 34060, Montpellier, France.

E-mail address: bernard.cuq@supagro.fr (B. Cuq).
} 
process for obtaining skim-milk powders with high rehydration ability, this technology has not yet really been considered in scientific studies. The main objectives of the present research is to study how the drying step during the steam-jet agglomeration of skim milk powders influences on the biochemical characteristics, structural parameters, and functional properties of the final agglomerates. The results will help to increase our knowledge and to build relationships between the process, structure and properties of skim milk powder agglomerates.

\section{Materials and methods}

\subsection{Raw materials}

Native skim-milk powder was obtained by spray-drying skim milk (Lactalis, France) using a pilot plant workshop (Bionov, France) under the following process conditions: atomization flow rate $=100 \mathrm{~L} \mathrm{~h}^{-1}$; inlet air temperature $=172{ }^{\circ} \mathrm{C}$; outlet air temperature $=72{ }^{\circ} \mathrm{C}$; and recycling of fines particles in the internal fluid-bed. Native powder was first characterized using standardized methods in triplicates (Schuck et al., 2012). The total nitrogen content $\left(35.7 \pm 0.1 \mathrm{~g} .100 \mathrm{~g}^{-1}\right)$, fat content $\left(<0.5 \mathrm{~g} .100 \mathrm{~g}^{-1}\right)$, and ash content $\left(7.83 \pm 0.02{\left.\mathrm{~g} .100 \mathrm{~g}^{-1}\right)}^{-1}\right.$ were determined by the Kjeldahl method, Gerber's acid-butyrometric method, and the incineration of dry matter, respectively. The free water content $\left(3.16 \pm 0.06 \mathrm{~g} .100 \mathrm{~g}^{-1}\right)$ and bound water content (1.40 $\pm 0.09 \mathrm{~g} .100 \mathrm{~g}^{-1}$ ) of native skim-milk powder were measured by weighing a small sample (about $1 \mathrm{~g}$ ) after oven drying at $102^{\circ} \mathrm{C}$ for $5 \mathrm{~h}$ and $7 \mathrm{~h}$ under vacuum, respectively (Schuck et al., 2012). The lactose

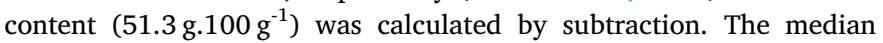
value of the Feret diameter of the native powder $(106 \pm 1 \mu \mathrm{m})$ was measured by an optical granulo-morphometer analyzer (Qicpic, Sympatec GmbH, Germany).

An amorphous spray-dried lactose powder was produced by rehydration of a commercial alpha-lactose powder (DFE Pharma) at $15 \mathrm{~g} .100 \mathrm{~g} \mathrm{~g}^{-1}$ water, and drying of the solution using a pilot-scale spraydryer (GEA Niro A/S, Mobile Minor Dryer). The enthalpy of crystallization of amorphous lactose $\left(82.2 \pm 1.1 \mathrm{~J} \mathrm{~g}^{-1}\right)$ was determined by differential scanning calorimetry according to Roos and Karel (1991).

\subsection{Steam jet agglomeration and drying processes}

The steam-jet agglomeration process of skim milk native powder was conducted using an original pilot device specifically designed for the present study (Fig. 1). It consisted of a vertical cylindrical tube of $100 \mathrm{~cm}$ length with an internal cross-section of $76 \mathrm{~mm}$. The skim milk powder was introduced at constant powder feed rate $\left(3.2 \mathrm{~kg} \mathrm{~h}^{-1}\right)$ at the top of the tube by means of a volumetric feeder (Gericke, Switzerland; type: GAC), and fell gravimetrically inside the vertical tube. Steam was generated by a boiler (Collard-Trolart, France) and introduced at constant steam flow rate $\left(1.7 \mathrm{~kg} \mathrm{~h}^{-1}\right)$ into the vertical tube $18.5 \mathrm{~cm}$ from the top. The steam/powder ratio is constant (0.53). During its fall, the

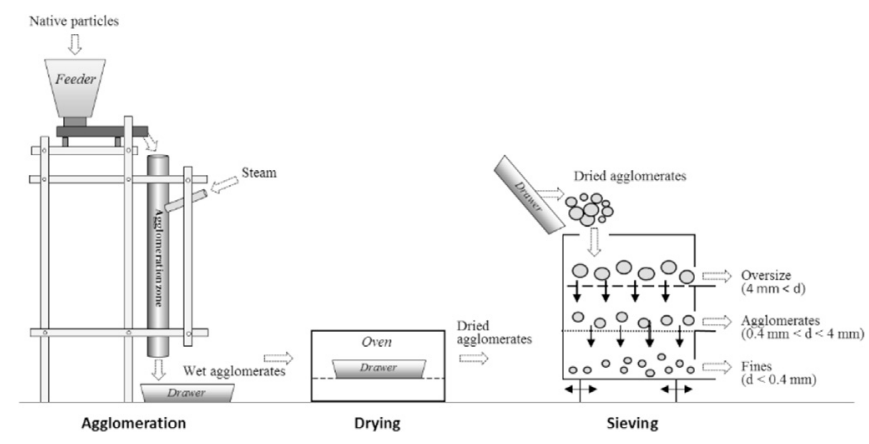

Fig. 1. Schematic description of the steam jet agglomeration pilot plant. powder was moistened by the steam flow inside the tube and agglomerated.

The wet agglomerates were collected at the bottom end of the tube. They were immediately spread as a thin layer (thickness of approximately $20 \mathrm{~mm}$ ) over a stainless steel plate and introduced into a static oven (Memmert $\mathrm{GmbH}$, Germany) for drying. The wet agglomerates were dried for different lengths of times $(0,5,15,30$, or $60 \mathrm{~min})$ at different temperatures $\left(70,90\right.$, or $\left.110^{\circ} \mathrm{C}\right)$ that were chosen accordingly to what is generally applied at an industrial scale. Due to technical constraints, the experimental error was assessed by triplicating the experiment at $110^{\circ} \mathrm{C}$. The resulting confidence interval was applied for drying experiments at 70 or $90^{\circ} \mathrm{C}$. The surface temperature reached by the agglomerates at the end of the drying stage was measured using an infra-red thermometer (Testo, Germany).

At the end of drying, the dried agglomerates were collected and manually sieved at ambient temperature over a column of two metallic sieves of decreasing mesh ( 4 and $0.4 \mathrm{~mm}$ ). This mesh size range was determined with regard to the values classically used in the milk powder agglomeration industry. The agglomerates were collected over the $0.4 \mathrm{~mm}$ sieve and stored inside hermetic plastic cups until characterization.

\subsection{Characterization of the agglomerates}

\subsubsection{Biochemical properties}

The water content of agglomerates was measured by weighing a small sample (about $1 \mathrm{~g}$ ) after oven drying at $102^{\circ} \mathrm{C}$ for $5 \mathrm{~h}$ (Schuck et al., 2012). Measurements were conducted in triplicate.

The non-denatured whey protein nitrogen content (WPNi) of the agglomerates $\left(\mathrm{g} \mathrm{N}^{-\mathrm{kg}^{-1}}\right.$ powder) was calculated as $\mathrm{WPNi}=\mathrm{NS}_{4.6}-$ $\mathrm{NS}_{12}$, where $\mathrm{NS}_{4.6}$ is the nitrogen content soluble at $\mathrm{pH} 4.6$ (g of N.kg ${ }^{-1}$ ) and $\mathrm{NS}_{12 \%}$ is the nitrogen content soluble in $12 \%$ trichloroacetic acid (g of N. $\mathrm{kg}^{-1}$ ). Measurements were conducted using standardized methods in triplicates (Schuck et al., 2012).

\subsubsection{Physical characteristics}

The size and shape characteristics of the agglomerates was determined by image analysis, using ImageJ analysis software (NISElements, Nikon, JP). Pictures of a $1 \mathrm{~g}$ sample (which represented about 200 and 600 agglomerates) were taken with a camera (Sony, Japan). The images were analysed to determine the size and shape characteristics. The Feret diameter is deducted from the projected area of the particles using a slide gauge. It is defined as the distance between two parallel tangents of the particle at an arbitrary angle. The shape of the particles was characterized by their circularity values, which consist of a measurement of the length/width particle relationship, and ranges between 1 (perfect circle) and 0 (needle shaped object). Measurements were conducted in triplicate.

The apparent density of the agglomerates was measured with a hydrostatic balance (Mettler Toledo, Switzerland). The compactness of the agglomerates was calculated using Eq. (1) (Rondet et al., 2009):

$\varphi=\frac{\rho a}{(1+w) \rho t}$

where $\rho_{\mathrm{a}}$ is the apparent density, $w$ is the water content of the agglomerates $\left(\mathrm{g} .100 \mathrm{~g}^{-1}\right)$ and $\rho_{\mathrm{t}}$ is the true density $\left(1416 \mathrm{~kg} \mathrm{~m}^{-3}\right)$ of the native skim-milk powder (Schuck et al., 2012).

Thermal behaviour of agglomerates was characterized by differential scanning calorimetry (DSC). A small sample of agglomerates (about 5-15 mg) was heated from $0{ }^{\circ} \mathrm{C}$ to $200{ }^{\circ} \mathrm{C}$, at a heating rate of $3^{\circ} \mathrm{C}$.min ${ }^{-1}$. Typical evolutions of DSC curves of skim milk powders with temperature clearly display glass transition under $60^{\circ} \mathrm{C}$, crystallisation between 90 and $130^{\circ} \mathrm{C}$, and Maillard reaction perturbations of the signals above $130^{\circ} \mathrm{C}$ (Vuataz, 2002; Morgan et al., 2005). The glass transition temperature $\left(\mathrm{T}_{\mathrm{g}}\right)$ was measured at the midpoint of the baseline shift. The crystallization enthalpy of the exothermic peak of 
the agglomerates was measured by integration of the surface of the peak. The amorphous lactose content of the agglomerates A was calculated using Eq. (2).

$A=\frac{\text { Ace }}{\left(\frac{L}{100}\right) \times \text { Lce }} \times 100$

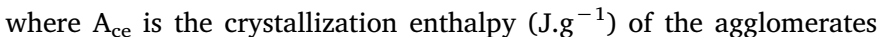
determined by DSC, $\mathrm{L}$ is the lactose content of the skim-milk powder (51.3 g. $100 \mathrm{~g}^{-1}$ dry matter), and $\mathrm{L}_{\mathrm{ce}}$ is the amorphous lactose crystallization enthalpy $\left(82 \mathrm{~J} \mathrm{~g}^{-1}\right)$.

The external microstructure of the agglomerates was observed using a DS-Ri1 camera (color mode: RGB; 16 bits per channel; $1280 \times 1024$ pixels) mounted on an AZ100 macroscope (Nikon, Japan) (magnifications from $\times 1$ to $\times 40$ ) in light reflection mode. For each slide position, series of 15-17 images with different focal planes were taken in order to compose an extended focus image (image composed of the sharpest pixels between the Z-series). In addition, mosaic images were assembled by reconstructing $2 \times 2$ extended focus images using NISElements imaging software (Nikon, Japan) operating on the AZ100 system.

\subsubsection{Functional analysis}

The wetting time of the dried agglomerates was determined by measuring the time required for $5 \mathrm{~g}$ of agglomerated powder to completely sink in $100 \mathrm{~mL}$ of water at $20^{\circ} \mathrm{C}$ contained in a $400-\mathrm{mL}$ beaker (diameter: $70 \mathrm{~mm}$, height: $135 \mathrm{~mm}$ height) (adapted from Schuck et al., 2012). Measurements were conducted in duplicate.

\subsection{Model fitting}

Apparent exponential curves converging to a limit value with time $\mathrm{x}$ were experimentally observed to describe the changes in the physicochemical characteristics of the agglomerates as a function of the drying time. We used a first-order equation (Eq. (3)) to describe the processtime dependence of experimental values (Bellocq et al., 2018).

$y=y_{0}+a\left(1-e^{-b x}\right)$

where $\mathrm{a}$ and $\mathrm{b}$ are the model coefficients related to the final plateau value, and the rate of the changes, respectively. The a and b coefficients were determined using the Excel 2013 solver (Microsoft, Redmond, WA, USA) while minimizing the sum of squared differences between the experimental values and the ones predicted by the model. The coefficient of determination $\mathrm{R}^{2}$ was used to gauge the goodness of fit. These coefficients were used to calculate the final plateau value $\left(y_{0}+a\right)$ and the characteristic drying time $(1 / \mathrm{b}$; min).

\section{Results}

3.1. Impact of the drying step on the characteristics and properties of the agglomerates

We first described the changes in the characteristics and properties of the skim milk agglomerates during the drying stage as a function of the drying time. Changes in surface temperature, water content and compactness during drying are presented in Fig. 2. For instance at $110^{\circ} \mathrm{C}$, the agglomerates surface temperature showed a rapid increase from 39 to $65^{\circ} \mathrm{C}$ after $15 \mathrm{~min}$, and continued to increase until reaching a final temperature of $83^{\circ} \mathrm{C}$ after $60 \mathrm{~min}$ of drying. As expected, a

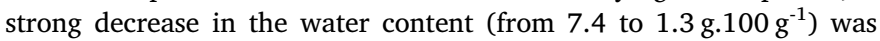
observed during this drying phase. The elimination of water during the drying induced a large increase in the compactness (from 0.86 to 0.92 ) of the agglomerates (Fig. 2c).

On the other hand, the size and the shape of the skim milk agglomerates were not affected by the drying stage. For instance at $110^{\circ} \mathrm{C}$, almost constant values of the median Feret diameter (a)

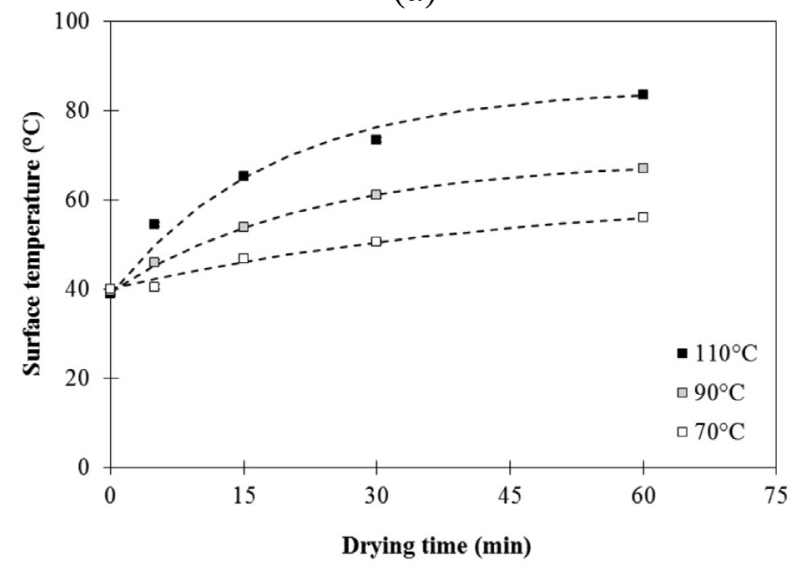

(b)

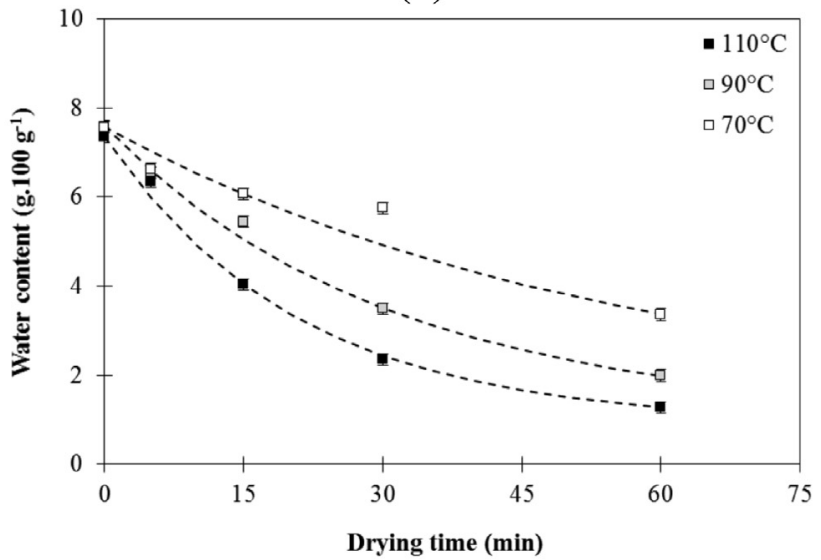

(c)

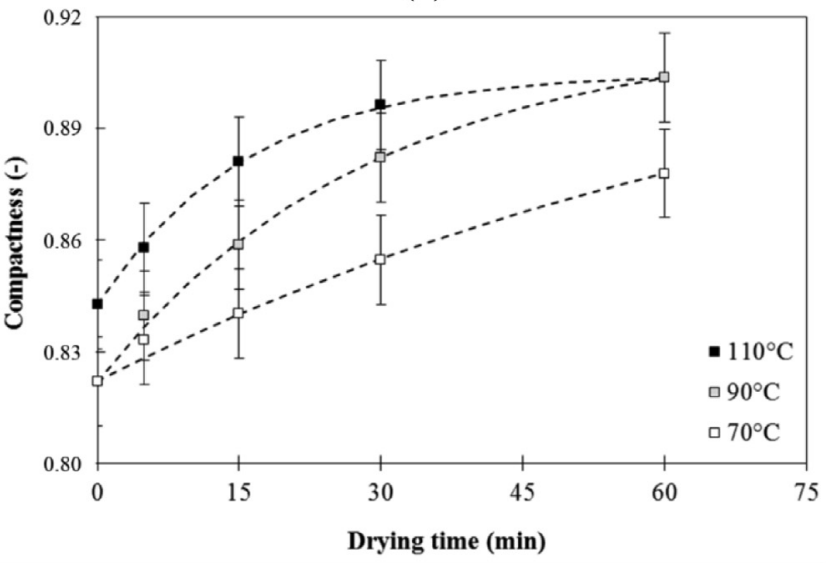

Fig. 2. Impact of the drying temperature $\left(70,90\right.$, or $\left.110^{\circ} \mathrm{C}\right)$ on the changes in surface temperature (a), water content (b) and compactness (c) of the agglomerates as a function of the time of the drying step. The dotted lines correspond to the model (eq (3)) used to fit the experimental data.

$(2.20 \pm 0.21 \mathrm{~mm})$ and circularity $(0.567 \pm 0.040)$ of the agglomerates (data not shown). In addition, no visible differences in the apparent external microstructure of agglomerates were observed, regardless of the drying time (Fig. 3). As well, the drying stage did not induce denaturation of soluble proteins, since almost constant values of WPNi $\left(5.72 \pm 0.10 \mathrm{~g} \mathrm{~N} \cdot \mathrm{kg}^{-1}\right)$ were measured on the agglomerates, regardless of the drying time (data not shown).

The changes in physical state (glass transition and crystallization rate) of the lactose fraction in skim milk agglomerates were monitored as a function of the drying time (Figs. 4 and 5). For instance during 


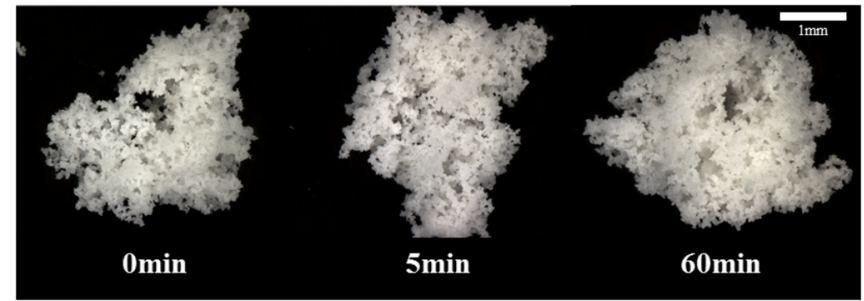

Fig. 3. Microstructure of the agglomerates of skim milk powder during drying at $110^{\circ} \mathrm{C}$ as a function of the drying times $(0,5$, or $60 \mathrm{~min})$.

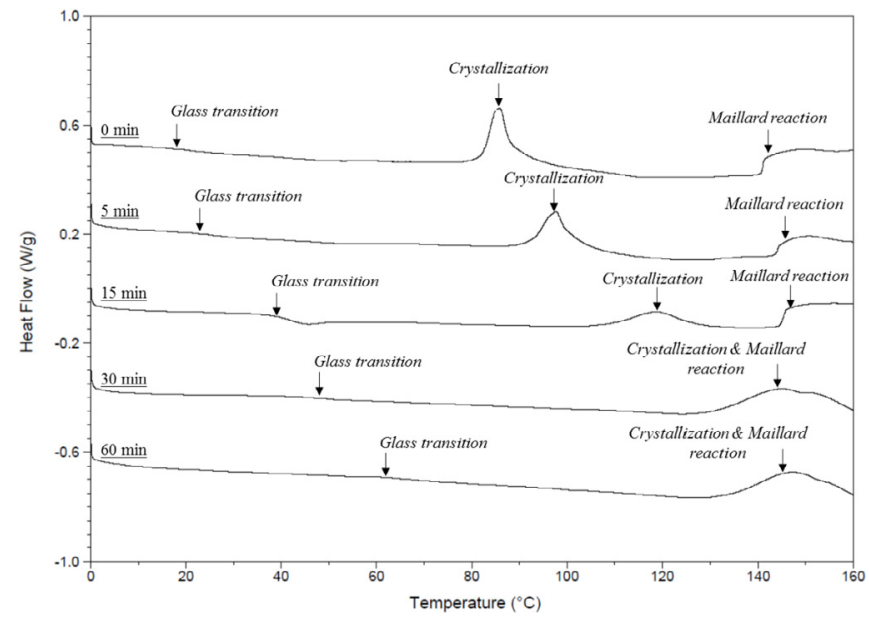

Fig. 4. DSC curves of the agglomerates dried at $110^{\circ} \mathrm{C}$. Glass transition and crystallization peaks are indicated by arrows in order to follow their progressive shift with drying time.

drying at $110^{\circ} \mathrm{C}$, the glass transition temperature showed a monotonous increase from $20^{\circ} \mathrm{C}$ at $0 \mathrm{~min}$ drying, to $67^{\circ} \mathrm{C}$ at $60 \mathrm{~min}$ drying. Before drying, the measured enthalpy of crystallization $\left(26 \mathrm{~J} \mathrm{~g}^{-1}\right)$ corresponded to an amorphous lactose content of $64 \%$. During drying, the value of enthalpy of crystallization sharply decreased $\left(12 \mathrm{~J} \mathrm{~g}^{-1}\right)$ to reach an amorphous lactose content of $29 \%$ at $15 \mathrm{~min}$ drying. The crystallisation peak of lactose could not be clearly identified by using DSC for longer drying times, since it overlapped the Maillard reaction peak.

Regarding the functional properties, the drying stage significantly impacted the rehydration properties of the skim milk agglomerates (Fig. 6). These latter showed poor rehydration properties before the drying stage, with a high value of wetting time $(35 \mathrm{~s})$. In the five first minutes of drying, the wetting time of the agglomerates strongly decreased to reach an optimum value (of $12 \mathrm{~s}$ for the drying at $110^{\circ} \mathrm{C}$ ). Above 5 min drying, the wetting time then linearly increased with the drying time. For instance, it reaches a high value of $41 \mathrm{~s}$ at $60 \mathrm{~min}$ drying at $110^{\circ} \mathrm{C}$.

A first order eq. (3) was used to describe the kinetics of the physicochemical changes induced by the drying stage (Figs. 2 and 5). The model was well adapted $\left(\mathrm{R}^{2}>0.931\right)$ to describe the physicochemical changes induced during the drying stage (Table 1), except for the ones concerning Feret diameter and circularity. As the variations of wetting time induced by the drying stage were not monotonous, the model could not be applied to this characteristic.

For instance at $110 \mathrm{C}$, quite similar calculated characteristic times $(1 / \mathrm{b}$ values) were found when describing the changes in surface temperature (e.g., $18.2 \mathrm{~min}$ ), water content $(20.7 \mathrm{~min})$ and compactness (15.7 min). This suggests functional links between the surface temperature, water evaporation and changes in compactness of the agglomerates during the drying step. On the other hand, the calculated characteristic times strongly differed when considering the changes in (a)

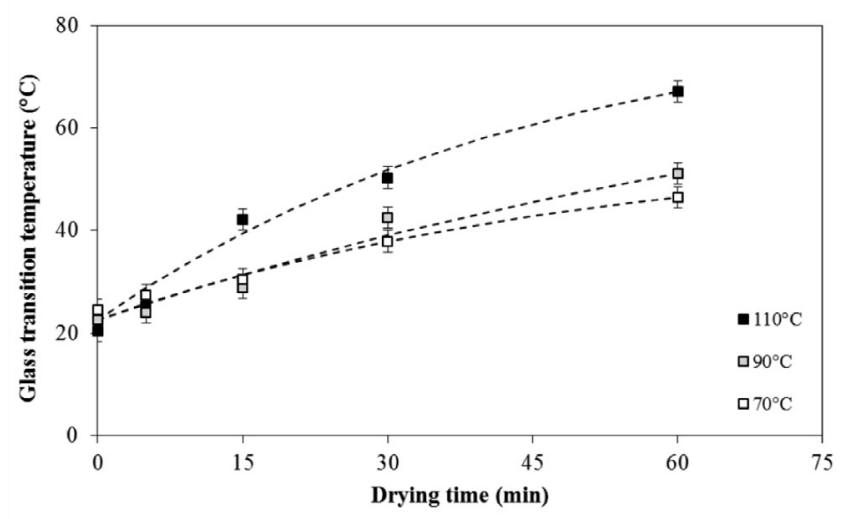

(b)

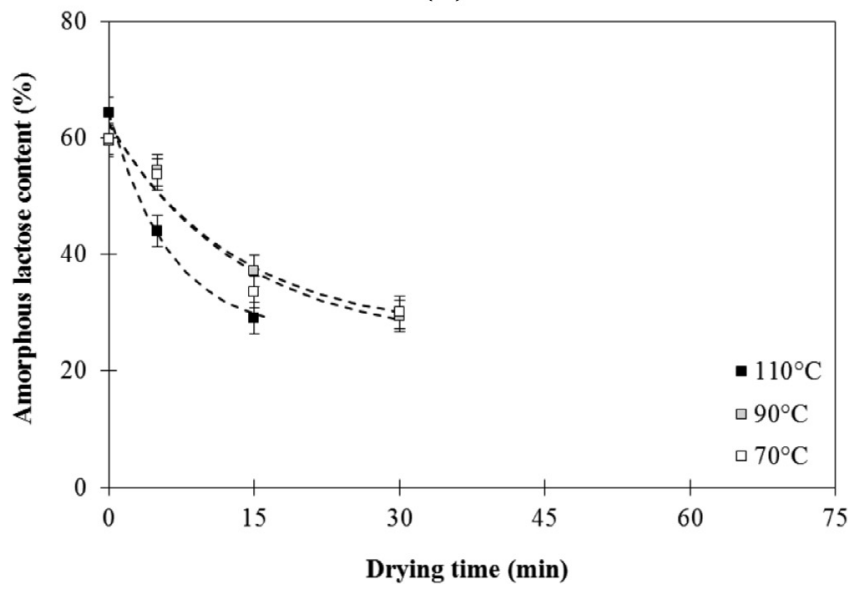

Fig. 5. Impact of the drying temperature $\left(70,90\right.$, or $\left.110^{\circ} \mathrm{C}\right)$ on the glass transition temperature (a) and amorphous lactose content (b) of the agglomerates as a function of the time of the drying step. The dotted lines correspond to the model (eq (3)) used to fit the experimental data.

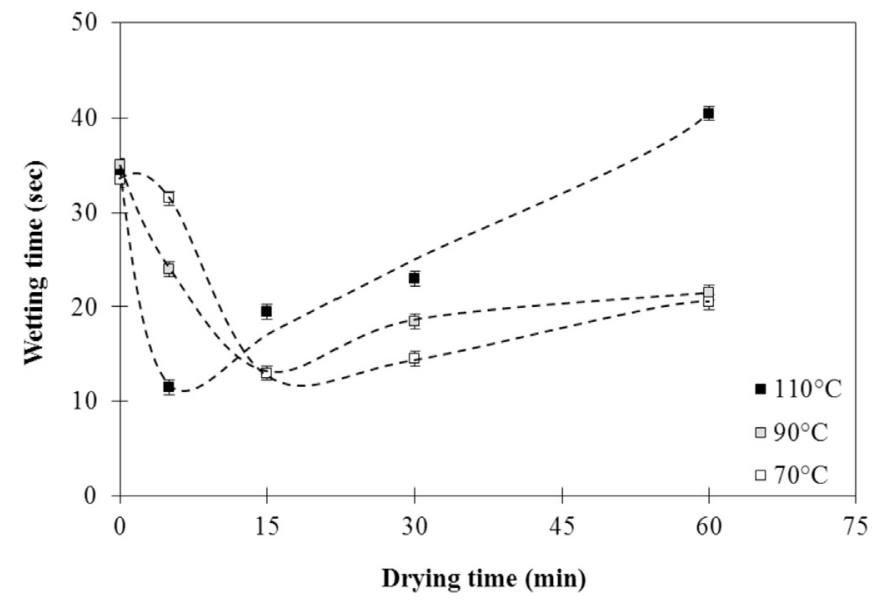

Fig. 6. Impact of the drying temperature $\left(70,90\right.$, or $\left.110^{\circ} \mathrm{C}\right)$ on the rehydration time of the agglomerates as a function of the time of the drying step.

glass transition temperature (38.5 $\mathrm{min}$ ) and content of amorphous lactose $(6.25 \mathrm{~min})$. The decrease in lactose amorphous content in the agglomerates was faster than the decrease in water content and the increase in the glass transition temperature during the drying step. 
Table 1

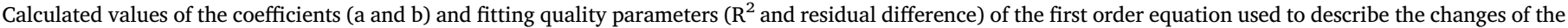
physicochemical characteristics of agglomerates, as a function of the drying time at different temperatures $\left(70,90\right.$, or $\left.110{ }^{\circ} \mathrm{C}\right)$.

\begin{tabular}{|c|c|c|c|c|c|c|c|}
\hline & Drying temperature $\left({ }^{\circ} \mathrm{C}\right)$ & Coef. a & Coef. b & Coefficient $\mathrm{y}_{0}+\mathrm{a}$ & Coefficient $1 / \mathrm{b}$ & $\mathrm{R}^{2}$ & Residual sum of square \\
\hline \multirow[t]{3}{*}{ Surface temperature $\left({ }^{\circ} \mathrm{C}\right)$} & 70 & 22.1 & 0.022 & 62.0 & 46.4 & 0.984 & 2.46 \\
\hline & 90 & 29.6 & 0.044 & 69.1 & 22.8 & 0.999 & 0.85 \\
\hline & 110 & 46.2 & 0.055 & 85.2 & 18.2 & 0.983 & 7.58 \\
\hline \multirow[t]{3}{*}{ Water content (\%) } & 70 & -6.47 & 0.017 & 1.09 & 57.3 & 0.931 & 1.22 \\
\hline & 90 & -6.48 & 0.033 & 1.10 & 30.2 & 0.993 & 0.45 \\
\hline & 110 & -6.42 & 0.048 & 0.93 & 20.7 & 0.996 & 0.45 \\
\hline \multirow[t]{3}{*}{ Compactness $(-)$} & 70 & 0.109 & 0.012 & 0.931 & 82.8 & 0.992 & 0.005 \\
\hline & 90 & 0.093 & 0.035 & 0.915 & 28.7 & 0.998 & 0.004 \\
\hline & 110 & 0.062 & 0.064 & 0.905 & 15.7 & 0.999 & 0.002 \\
\hline \multirow[t]{3}{*}{ Feret diameter $(\mathrm{mm})$} & 70 & 1.457 & 0.008 & 3.31 & 124 & 0.933 & 0.250 \\
\hline & 90 & 1.500 & 0.008 & 3.35 & 125 & 0.171 & 0.951 \\
\hline & 110 & 0.398 & 0.005 & 2.58 & 200 & 0.126 & 0.790 \\
\hline \multirow[t]{3}{*}{ Circularity $(-)$} & 70 & -0.150 & 0.030 & 0.510 & 33.3 & 0.751 & 0.112 \\
\hline & 90 & -0.080 & 0.065 & 0.570 & 15.4 & 0.874 & 0.056 \\
\hline & 110 & -0.010 & 0.004 & 0.580 & 285.7 & 0.002 & 0.160 \\
\hline \multirow[t]{3}{*}{ Glass transition temperature $\left({ }^{\circ} \mathrm{C}\right)$} & 70 & 37.5 & 0.016 & 61.0 & 62.5 & 0.992 & 3.56 \\
\hline & 90 & 45.5 & 0.019 & 65.8 & 52.6 & 0.971 & 7.94 \\
\hline & 110 & 63.0 & 0.026 & 81.0 & 38.5 & 0.989 & 8.98 \\
\hline \multirow[t]{3}{*}{ Amorphous lactose content (\%) } & 70 & -37.5 & 0.075 & 24.9 & 13.33 & 0.956 & 10.37 \\
\hline & 90 & -35.7 & 0.078 & 26.7 & 12.82 & 0.964 & 7.82 \\
\hline & 110 & -38.0 & 0.160 & 26.4 & 6.25 & 0.999 & 1.23 \\
\hline
\end{tabular}

\subsection{Influence of the drying temperature}

The impact of the drying temperature $\left(70,90\right.$, or $\left.110^{\circ} \mathrm{C}\right)$ on the physicochemical changes induced by the drying stage was evaluated (Fig. 2). Decreasing the drying temperature from 110 to $70{ }^{\circ} \mathrm{C}$ did not change the shape of drying kinetics curves. It can be assumed that similar mechanisms are involved but at different rates, since we observed significant effects of the drying temperature on the kinetic model parameters (Table 1). As expected, decreasing the drying temperature slowed down the physicochemical changes and resulted in higher calculated values of the characteristic times for the different mechanisms (Table 1). We also observed that decreasing the drying temperature induced lower surface temperatures, higher water content, and lower compactness of the agglomerates. The median values of the Feret diameter, the circularity factor and the extent of protein denaturation (WPNi) remain the same during the drying phase when conducted at 90 or $70{ }^{\circ} \mathrm{C}$ (data not shown).

Decreasing the drying temperature from 110 to $70{ }^{\circ} \mathrm{C}$ influenced the rate of changes related to the physicochemical state of lactose (Fig. 5). The values of the characteristic time were higher for the changes in the glass transition temperature $(51 \mathrm{~min})$ and for the decrease of the amorphous lactose content (13.3 $\mathrm{min})$.

The changes in the wetting time of agglomerates during the drying process showed similar trends, regardless the drying temperature, with a decrease down to an optimum (i.e., minimum wetting time) in the first minutes of drying, followed by a linear increase until the end of drying (Fig. 6). Decreasing the drying temperature from 110 to $70{ }^{\circ} \mathrm{C}$ increased the drying time required to reach the minimum value of wetting time (from 5 to $17 \mathrm{~min}$ ) and decreased the final value of the wetting time (from 41 to $21 \mathrm{~s}$ ).

\section{Discussion}

The primary objective of the drying stage during the steam jet granulation process is to remove the water absorbed by the powder during steam exposure. The process parameters (temperature) of the drying stage significantly impacted the water evaporation kinetics.
Water removal made it possible to reduce both the water content (Fig. 2b) and the water activity of the agglomerated skim milk powders. Water content must be lower than $4 \%$ and water activity lower than 0.2 to ensure shelf life and to avoid caking or microbial proliferation during storage (Schuck et al., 2007).

The present study demonstrated a strong influence of the drying step on the rehydration properties (wetting times) of the agglomerates (Fig. 6). The measured values of wetting time ranged between 11 and $42 \mathrm{~s}$ depending on the drying conditions. It is assumed that the rehydration properties depend on the changes in water content of the agglomerates during the drying stage, whatever the drying temperature (Fig. 7). The results demonstrated two different phases during the drying stage. During the first minutes of drying (from 0 to 5-15 min), the rapid decreases in water content (from 7.5 to $6 \mathrm{~g} .100 \mathrm{~g}^{-1}$ ) was associated with large decreases in the values of wetting time (from 35 to 10-15 s). During the second phase of drying for longer periods (above $5-15 \mathrm{~min}$ ), the progressive and slight decrease in the water content (from 6 to $2 \mathrm{~g} .100 \mathrm{~g}^{-1}$ ) is concomitant with increases in the values of

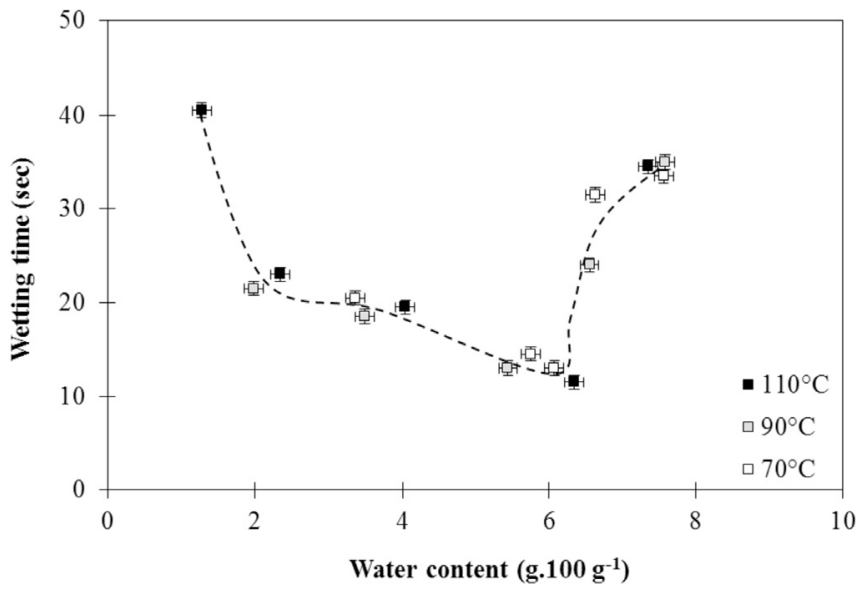

Fig. 7. Impact of water content of the agglomerates on their rehydration time. 


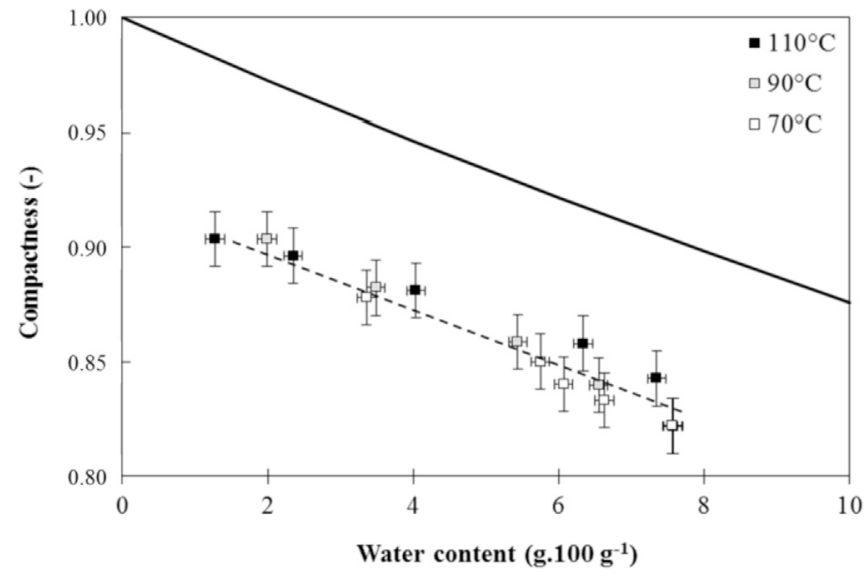

Fig. 8. Hydro-textural description (compactness vs. water content) of skim milk agglomerates during drying under different conditions (times and temperature).

wetting time (from 10 to $15-40$ s). The water content of the agglomerates was found to be a key factor impacting the rehydration behaviour of the skim milk powders agglomerated by the steam-jet process. An optimum wetting time range, around $10-15 \mathrm{~s}$, could be reached during the drying process.

It is known that the diameter distribution and the shape characteristics of dairy powder strongly impact on their wetting and sinking properties (Gaiani et al., 2007; Ji et al., 2016). The present study investigated the changes in size and structure characteristic of the agglomerates induced by during the drying stage. We did not find a significant influence of the drying stage on the size, and shape characteristics of the agglomerates, regardless of the drying temperature. Drying only induced a slight significant increase in compactness of the agglomerates. The impact of process parameters during the drying stages on the values of compactness and water content can be discussed using the hydrotextural diagram (Rondet et al., 2009; Ruiz et al., 2011) (Fig. 8). This phase diagram is limited in its upper part by the saturation curve, which represents the maximum water content that an agglomerate of a given constant compactness can contain. The region below the saturation curve corresponds to unsaturated state, with liquid and porous arrangements. After the steam-jet agglomeration process, the wet agglomerates are located below the saturation curve, since the porous grains are not fully saturated by water. The drying stage impacts the hydrotextural parameters of the agglomerates. During drying, the decrease in water content of the wet grains is concomitant with an increase in their compactness, regardless of the drying temperature (Fig. 8). Regardless of the process parameters, the agglomerate structure generated by the steam-jet process maintains their porous structure during the drying stage (Fig. 3), since the gap with the saturation curve remains almost constant (Fig. 8). The changes in water content and compactness were not coupled with changes in diameter, as no shrinkage of the agglomerates was induced by the drying stage. The water extraction did not generate mechanical constraints able to deform the structure of the agglomerates, and the internal structure characteristics (porosity and capillary network) of the agglomerates were not impacted by the drying stage. The porous structure of the skim milk agglomerates thus strongly depend on the agglomeration mechanisms during the steam-jet process, and are not impacted by the drying stage.

The drying mechanisms of the agglomerated skim milk powders were also described by investigating the physicochemical states of the milk components, and their impacts on the rehydration behaviour of the agglomerates. The protein fraction is the second main component (35\% of the total solids) of the skim milk powders after lactose. Thermal denaturation of soluble proteins may occur during the production of skim milk powder (Schuck, 2011). In the present study, no (a)

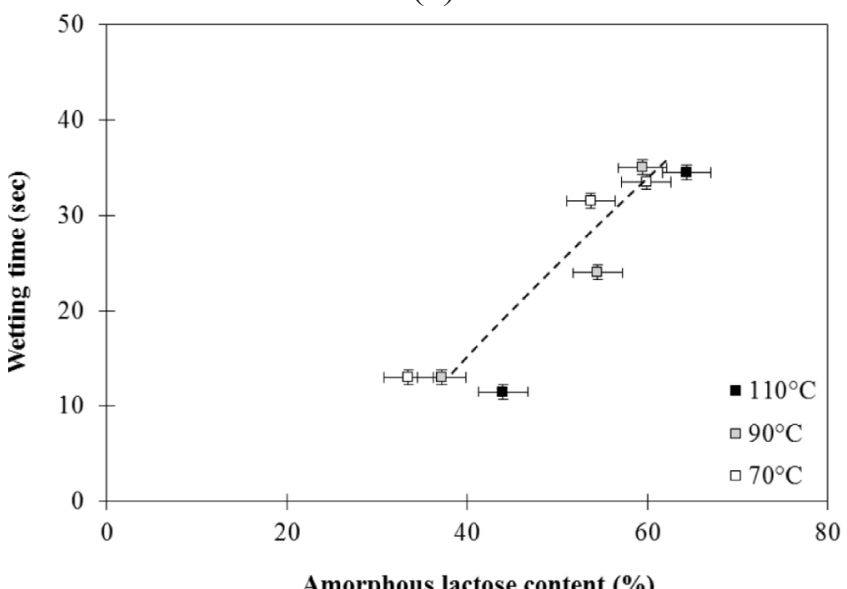

(b)

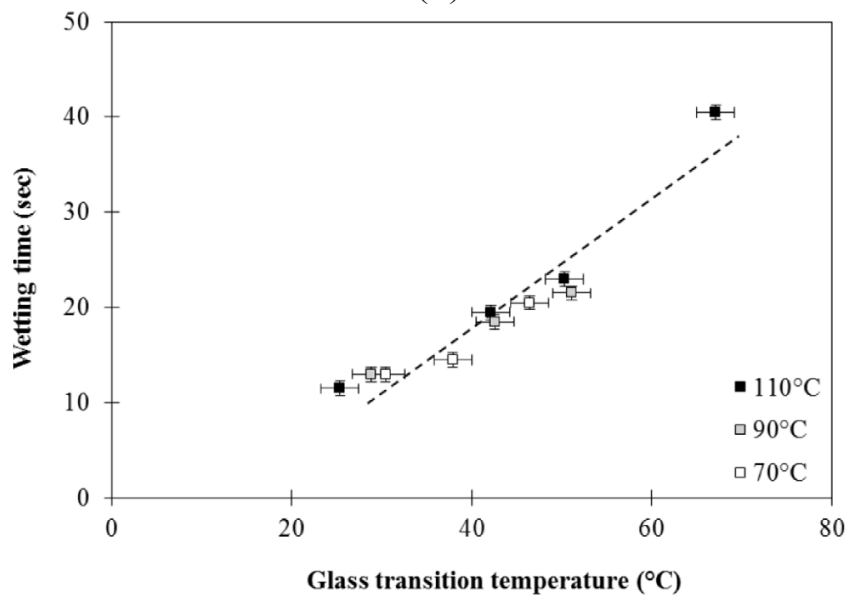

Fig. 9. Relationship between the amorphous content and the wetting time of the agglomerates (a) from data collected the first phase of drying. Relationship between the glass transition temperature and the wetting time of the agglomerates (b) from data collected the second phase of drying.

protein denaturation was observed during the drying stage. The low water content of the powder after steam-jet agglomeration and during drying probably did not make it possible to reach a high enough molecular mobility to allow protein denaturation.

Lactose represents about $50-55 \%$ of the total solids weight of the skim milk powders. Lactose can exist in different crystalline and amorphous forms in dairy products. These forms affect lactose behavior and impact the powder properties. Crystalline monohydrated lactose is known to be poorly soluble in water (Roos, 2009). The present study demonstrated that crystallization mechanisms of lactose can occur during the drying stage of wet agglomerates (Fig. 4). These mechanisms were slightly slowed down when drying at lower temperatures (Yazdanpanah and Langrish, 2011). Crystallization of lactose was correlated with the improvement in agglomerates rehydration behavior, as observed during the first phase of drying stage, regardless of the temperature (Fig. 9a). Amorphous lactose present at the surface of the agglomerates is hygroscopic and may dissolves quickly, thus locally thickening the liquid in the boundary of the agglomerates at a point that could impede the penetration of water through capillarity (Kim et al., 2002; Palzer, 2005). During the second phase of drying, once the lactose has been partially crystallized, the glass transition temperature of the agglomerates can be correlated with the wetting time of the agglomerates (Fig. 9b). Long drying times and low water contents resulted in longer wetting times. Lowering the water content by drying 
then leads to an increase in the glass transition temperature of the agglomerates. At low water content, the difference between the glass transition temperature and the temperature of water for the rehydration test $\left(20^{\circ} \mathrm{C}\right)$ is high. This difference being known to strongly influence the relaxation behavior of the material over time, the plasticizing effect of the water on the agglomerates that is required for solid bridges dissolution during rehydration should be delayed (Williams et al., 1955; Roos, 2002).

\section{Conclusions}

The steam-jet agglomeration pilot plant designed in this research made it possible to study the agglomeration mechanisms of skim milk powder and more specifically to evaluate the influence of the drying stage on the agglomerates properties. The drying conditions (time and temperature) showed a huge impact on the water evaporation kinetics. However, changing the drying conditions did not significantly impact on the structure properties of the skim milk agglomerates, in the range of conditions studied in this paper. The structure properties of agglomerates of skim milk were shown to be controlled by the steam-jet agglomeration stage. A strong relationship between the water content and the wetting time of the agglomerates was demonstrated. During the first part of the drying stage, decreasing the water content improved the rehydration behavior of the agglomerates. This positive influence on rehydration was shown to be linked to favored lactose crystallization. During the second part of the drying stage, the low water content reduced the rehydration behavior of the agglomerates. This negative effect was associated with the increase in the glass transition temperature of the agglomerates, leading to a delay in water plasticization during rehydration. The drying stage is thus key process parameter to be controlled in order to reach optimal instant properties.

\section{References}

Barkouti, A., Turchiuli, C., Carcel, J.A., Dumoulin, E., 2013. Milk powder agglomerate growth and properties in fluidized bed agglomeration. Dairy Sci. Technol. 93, 523-535.

Bellocq, B., Ruiz, T., Cuq, B., 2018. Contribution of the cooking and drying stages on the structure of the couscous grains of durum wheat semolina. Cereal Chem. http://dx. doi.org/10.1002/cche.10078. (in press).

Forny, L., Marabi, A., Palzer, S., 2011. Wetting, disintegration and dissolution of agglomerated water soluble powders. Powder Technol. 206 (1), 72-78.

Gaiani, C., Schuck, P., Scher, J., Desobry, S., Banon, S., 2007. Dairy powder rehydration: influence of protein state, incorporation mode, and agglomeration. J. Dairy Sci. 90 (2), 570-581.

Hogekamp, S., 1999. Steam jet agglomeration - Part 1: production of redispersible agglomerates by steam jet agglomeration. Chem. Eng. Technol. 22 (5), 421-424.
Ji, J., Cronin, K., Fitzpatrick, J., Fenelon, M., Miao, S., 2015. Effects of fluid bed ag glomeration on the structure modification and reconstitution behaviour of milk protein isolate powders. J. Food Eng. 167, 175-182.

Ji, J., Fitzpatrick, J., Cronin, K., Maguire, P., Zhang, H., Miao, S., 2016. Rehydration behaviours of high protein dairy powders: the influence of agglomeration on wettability, dispersibility and solubility. Food Hydrocolloids 58, 194-203.

Jinapong, N., Suphantharika, M., Jamnong, P., 2008. Production of instant soymilk powders by ultrafiltration, spray drying and fluidized bed agglomeration. J. Food Eng. 84 (2), 194-205.

Kim, E.H.J., Chen, X.D., Pearce, D., 2002. Surface characterization of four industrial spray-dried dairy powders in relation to chemical composition, structure and wetting property. Colloids Surfaces B Biointerfaces 26, 197-212.

Malafronte, L., Ahrné, L., Robertiello, V., Innings, F., Rasmuson, A., 2016. Coalescence and agglomeration of individual particles of skim milk during convective drying. J. Food Eng. 175, 15-23.

Morgan, F., Appolonia Nouzille, C., Baechler, R., Vuataz, G., Raemy, A., 2005. Lactose crystallisation and early Maillard reaction in skim milk powder and whey protein concentrates. Lait 85 (4-5), 315-323.

Palzer, S., 2005. The effect of glass transition on the desired and undesired agglomeration of amorphous food powders. Chem. Eng. Sci. 60, 3959-3968.

Palzer, S., 2011. Agglomeration of pharmaceutical, detergent, chemical and food powders - similarities and differences of materials and processes. Powder Technol. 206, 1-17.

Rondet, E., Delalonde, M., Ruiz, T., Desfours, J.P., 2009. Identification of granular compactness during the kneading of a humidified cohesive powder. Powder Technol. 191, 7-12.

Roos, Y., Karel, M., 1991. Plasticizing effect of water on thermal behavior and crystallization of amorphous food models. J. Food Sci. 56 (1), 38-43.

Roos, Y., 2002. Importance of glass transition and water activity to spray drying and stability of dairy powders. Lait $82,475-484$.

Roos, Y., 2009. Solid and liquid states of lactose. Adv. Dairy Chem. 3, 17-33.

Ruiz, T., Deladonde, M., Bataille, B., Baylac, G., Dupuy de Crescenzo, C., 2005. Texturing unsaturated granular media submitted to compaction and kneading processes. Powder Technol. 154, 43-53.

Schuck, P., Mejean, S., Dolivet, A., Jeantet, R., Bhandari, B., 2007. Keeping quality of dairy ingredients. Lait 87, 481-488.

Schuck, P., 2011. Modifications des propriétés fonctionnelles des poudres de protéines laitières: impact de la concentration et du séchage. Innovat. Agron. 13, 71-99.

Schuck, P., Dolivet, A., Jeantet, R., 2012. Analytical Methods for Food and Dairy Powders. Wiley-Blackwell, Oxford.

Schuchmann, H., 1995. Production of instant foods by jet agglomeration. Food Contr. 6 (2), 95-100.

Shanmugam, S., 2015. Granulation techniques and technologies: recent progresses. Bioimpacts 5 (1), 55-63.

Turchiuli, C., Smail, R., Dumoulin, E., 2013. Fluidized bed agglomeration of skim milk powder: analysis of sampling for the follow-up of agglomerate growth. Powder Technol. 238, 161-168.

Vissotto, F.Z., Jorge, L.C., Makita, G.T., Rodrigues, M.I., Menegalli, F.C., 2010. Influence of the process parameters and sugar granulometry on cocoa beverage powder steam agglomeration. J. Food Eng. 97, 283-291.

Vuataz, G., 2002. The phase diagram of milk: a new tool for optimizing the drying process. Lait 82, 485-500.

Williams, M.L., Landel, R.F., Ferry, J.D., 1955. The temperature dependence of relaxation mechanisms in amorphous polymers and other glass-forming liquids. J. Am. Chem. Soc. $77,3701-3707$.

Yazdanpanah, N., Langrish, T.A.G., 2011. Fast crystallization of lactose and milk powder in fluidized bed dryer/crystallizer. Dairy Sci. Technol. 91, 323-340. 